\title{
FORMAL LEARNING AND DEVELOPMENT PROGRAMS OF HEC FOR THE IMPROVEMENT OF EDUCATION SECTOR
}

\author{
Qurat-ul-Ain Saleem \\ Aqil Shakoor ${ }^{* *}$ \\ Shabib ul Hassan ${ }^{* * *}$
}

\begin{abstract}
We are living in an era of development and innovation through research and learning. The nation that has achieved its development goals, has done through education reforms and a keen focus on strengthening its National Innovation System. In Pakistan, this role has fallen to the Higher Education Commission, commonly known as HEC. The Higher Education Commission (HEC) has attempted various activities for ceaseless improvement of the nature of advanced education as per the worldwide norms and to patch up post-auxiliary instruction to improve the instructive guidelines at the alumni level. Public Academy for Higher Education has been built up with the mean to plan and convey nonexclusive and need-based limit building and preparing programs in instructing and exploration for personnel just as a spotlight on scholastic administration and authority for the workforce and the board. Education Testing Council (ETC) has additionally been modified to normalize passage tests for the universities of Pakistan. The study focuses on the different programs run by HEC to develop the country's formal learning program and education sector. Since its commencement, we investigate various projects created by HEC to encourage Higher Education Institutions (HEIs) and build up a superior staff for this reason.
\end{abstract}

Keywords: HEC; Formal learning; developmental programs; education sector

\section{Introduction}

The HEC (Higher Education Commission), is Pakistan state's administrative authority with primary elements of subsidizing, managing, directing and authorizing the advanced education foundations in the nation. HEC was well-known in 1974 as UGC (University Grants Commission) ${ }^{1,2}$. In 2002 it accepting its cutting-edge structure as HEC under the command of Dr. Atta ur Rahman, FRS, its establishing director ${ }^{3}$. The commission is

\footnotetext{
This work is Licensed under a Creative Commons Attribution-Non-Commercial 4.0 International License. (c) (1) (8)

* Qurat ul Ain Saleem, Research Scholar, Pakistan Institute of Rehabilitation \& Medical Sciences, PIRMS Karachi

${ }_{* *}^{*}$ Aqil Shakoor, Research Scholar, Pakistan Institute of Rehabilitation \& Medical Sciences, PIRMS Karachi

${ }^{* * * *}$ Shabib ul Hassan, Ph.D. Professor and Vice Chancellor, Hamdard University, Karachi

${ }^{1}$ Parveen, Azra, Khalid Rashid, Muhammad Zafar Iqbal, and Sanaullah Khan. "System and reforms of higher education in Pakistan." International Journal of Business and Social Science 2, no. 20 (2011)

2 Voelter, Wolfgang. The Golden Period, Dawn Area Studies, 2008.

3 Ansari, Seema, Javier Poncela, Pablo Otero, Adeel Ansari, and Osama Mahfooz. "Research in Pakistan:

Structure, Funding and Results." Pakistan Journal of Engineering, Technology \& Science 5 (1), 2016
} 
accountable for detailing higher education plans and quality confirmation to fulfill the worldwide parameters as giving accrediting scholarly degrees, enhancement of new foundations and elevating of present establishments of Pakistan. The symbolic improvements in advanced education happened in 2002-200 under the authority of Prof. Atta ur Rahman. Prof. Atta-ur-Rahman stepped down in fight in 2008 due to the deferment of grants of thousands of students studying abroad by then legislature of Pakistan Peoples' Party. After which the college improvement programs eased back down as the Pakistan Peoples' Party's legislature presented huge spending cut and intensely convoluted regulatory methodology.

\section{Mission Statement}

The statement of purpose of HEC is the 'improvement and advancement of advanced education, innovative work in Pakistan ${ }^{4}$. Its central goal, thusly, is: "to encourage establishments of advanced education to fill in as motors of development for the financial improvement of Pakistan." The accentuation on financial development unmistakably portrays the concentration and bearings for HEIs research.

\section{Vision 2025}

A significant push will be to put Pakistan on the innovation map of the world through centered innovative work.

The solid accentuation on exploration and advancement is apparent in the Vision2025:"We will rearrange the momentum conventional Western arrangement of advanced education into a combination of structure of scholastic offices to make new learning, examination, and information.

We will assemble overall instruction and examination organization of colleges which will permit establishments to start research through government and the private area centered help empowering them to manufacture a global association program.

The Vision puts a solid accentuation on "information, advancement and business" as "key drivers of future advancement" (Prime Minister's Message, p. vii) in the "globalized world."

The Vision 2025 likewise recognizes the 'powers of innovation and information, which have altogether changed the manner in which we lead exchanges, interface with one another, make esteem, and produce business.

The rules for HEIs and HEC to upgrade and fortify 'Exploration and Innovation' in the nation are additionally unmistakably and unequivocally expressed

In the previous one of the missing connections in the advancement system was a distinction between the science and innovation foundations and the profitable

\footnotetext{
${ }^{4}$ Higher Education Commission. 2016. Higher Education Medium Term Development Framework 2011-15. (Islamabad: Higher Education Commission, 2016), 8.
} 
parts. The Vision tries to defeat this distinction so as to energize the ID of indigenous answers for nearby issues. This will require patching up S\&T associations, particularly those that may have gotten torpid. Potential outcomes of coordinated effort with private segment 'Hello tech' organizations to revive existing R\&D arrangements and rebuilding of ICT R\&D assets to keep away from deception will be investigated. Pakistan likewise falls behind others as far as development and licenses enrolled, which are the most popular proportions of achievement in science and innovation.

The vision puts a significant accentuation on "Financial Relevance,"

Thorough changes, involving definite activities in educational plan, teaching method, innovation, administration, evaluation just as social and financial significance will be made in the instructive system.

We will advance tweaked educational plan in the colleges and custom-made scholarly degree projects to react to the interest of industry and to overcome any issues between what colleges instruct and what organizations and industry need.

We will make a "Reserve for University Job Creation" to encourage the connection among teachers and understudies and to create linkages between advanced education market and the work market. ${ }^{5}$

\section{Research Questions}

Q1: What is the role of HEC in HEI?

Q2: What are the projects of HEC to enhance the learning environment?

\section{Literature Review}

The most imperative function of the commission is to encourage the improvement of advanced instructive structure in the country with principle center around rebuild the universities and degree awarding institutions in country to be a middle purpose of the high learning of training, innovative work. In particular HEC has been giving out many doctoral grants for instruction abroad consistently to assemble an information-based economy.

The fundamental territories the commission regulates are:

- Attestation

- Aptitude Test Council

- Faculty Enhancement

- Curriculum improvement

- Higher training foundation improvement

- Indigenous grants

\footnotetext{
${ }^{5}$ Higher Education Commission. 2017. HEC Vision 2025.

https://www.hec.gov.pk/english/HECAnnouncements/Documents/Announcement/HEC-Vision-2025.pdf.
} 
- Foreign grants

- Patent recording support

- Conference travel awards

- Increase industry and college research coordinated effort

- Developing new innovation parks

- Allocating research awards.

- Supporting distinctive exploration ventures.

Considering these capacities, the HEC has been running many projects to encourage the learning condition of the nation throughout the long term.

\section{Projects to enhance the Learning Environment of the Country}

The extent of HEC is extremely huge. It surrounds the entire of nation's instruction framework as such it has been taking a shot at various improvement programs considering diverse central focuses. The fundamental extents of the HEC programs are

- Standardization of nation's instruction framework.

- Development of HEIs as per global norms.

- Facilitating Education Programs for oppressed.

- Development of staff to meet the developing training needs of nation.

- Development of Curriculum in accordance with worldwide norms just as neighborhood needs.

- Development of exploration and advancement arrangement of nation.

- Development of between connection among industry and HEIs of the nation

- International Collaboration for Higher Education and Research

\section{Standardization of Country's Education System}

HEC's primary center has been to normalize nation's instruction framework and bring it upto worldwide guidelines. In this respect a great deal of work has been finished. The advancement of QAA has been the above all else step toward this path.

\section{Quality Assurance Agency}

In 2005, Government of Pakistan built up an office by the name of QAA (Quality Assurance Agency) under Higher Education Commission with the vision "To advance, improve and guarantee the nature of advanced education across HEIs in Pakistan"

QAA is an provision making and testing association whose activity is enhance and assurance of value in Advanced Education Organizations by methodical usage of value improvement strategies/rules so better degrees of worldwide standards at organizational level could be achieved.

\footnotetext{
${ }^{6}$ HEC. 2021. Quality Assurance Agency. https://www.hec.gov.pk/english/services/universities/QAA/Pages/default.aspx. —. 2021. The Modern University Program.
} 
QAA is completely practical with subsidizing and calculated help from HEC. It works together with the (QAD) Quality Assurance Division of Higher Education Commission while the (QAC) Quality Assurance Committee fills in as its Advisory board.

\section{The objectives of QAA}

- To shield enthusiasm of public by upholding great exercises in instruction \& empowering constant improvement in quality in advanced education.

- Policy making and advancement of handy rules of value confirmation identified with the further extent programs.

- Making rules for foundation of Quality Enhancement Cells and their Evaluation and Monitoring.

- To improve the norm of value affirmation by capacity working in higher education at public level.

- To screen and manage Higher Education Institutions for execution of adjustments to enhance standards of higher education in Pakistan.

QAA creates down to earth rules and approaches for building up Quality Improvement Cells at public segment colleges for combination of value affirmation in the advanced educational framework. It screens, assesses and helps in Capacity Building of all Quality Enhancement Cells. It gives preparing to staff of Quality Improvement Cells to fill in as Trainers. It encourages advancement of the degrees of worldwide similarity through ability improvement in the particular fields. It conducts preparing, workshops and courses through employing neighborhood just as unfamiliar specialists for the QAA and QEC $\operatorname{staff}^{7,8}$.

\section{Advancement of HEIs according to International Standards The Modern University Governance (MUG) Program for University Management}

The Modern University Governance (MUG) Program for University Management intends to furnish college the executives with the most recent administration devices, and to overcome any barrier among the board and the scholarly community ${ }^{9}$.

The primary action was taken for the top administration of colleges when LID and AIT Bangkok together directed the principal ever fourteen day workshop on " Good Governance for 21st Century " from 22nd May - June 01, 2007. The workshop zeroed in

\footnotetext{
${ }^{7}$ Bhutani, S. "Re-Searching Agriculture in South Asia: The law and policy context for agricultural research and development and its impact on smallholder farmers." (London: International Institute for Environment and Development (IIED),2013)

${ }^{8}$ Bukhari, S. M. H., and M Asim. "Policy Making and Is Impacts on Higher Education: A Comparative Study of Iran and Pakistan in 21st Century." Policy 5 (1), 2013.

9 The Modern University Program. (2021).

https://www.hec.gov.pk/english/services/faculty/MUGUA/Pages/Introduction.aspx.
} 
on great administration models and comprehensive vital administration standards, and was gone to by 12 college Vice Chancellors and 2 senior enlistment centers. The workshop additionally added visits and gatherings at driving Thai colleges and innovation stops, and relevant exploration associations. In that visit, further MOUs were marked between singular colleges and Vice Chancellors of Pakistan.

After the accomplishment of program, the Higher Education Commission chose with the help of heads of Higher Education Institutions to begin a standard in-administration program named Modern University Governance (MUG) Program for University Management for all levels of college the executives. From that point forward, LID has been executing exercises at ordinary stretches as per the accompanying system ${ }^{10}$ :

Principle exercises of Modern University Governance for University Management program are:

- Orientation Leadership Training Program for Newly recruited VCs Higher Education Institutions of Pakistan

- Leadership Training Program for Newly recruited VCs Higher Education Institutions of Pakistan

- Leadership Training Program for Senior Management Higher Education Institutions of Pakistan (HEC 2021)

\section{Positioning of Pakistani Higher Education Institutions}

Activity of QS positioning was taken up by HEC with the goal to advance a culture of partaking on the planet college rankings to get sensible impression of advanced education (HEIs) improvement in the nation.

HEC-Pakistan is the first in the Islamic world that has created Ranking rules, technique directed positioning activity. Activity of QS positioning is taken up by the HEC to advance a culture of taking an interest on the planet college rankings to get sensible impression of advanced education (HEIs) improvement in the nation.

\section{Grant for Repair and Maintenance of Scientific Equipment}

Bleeding edge research in the advanced education part requires best in class offices. To guarantee that Pakistan's colleges approach the best lab hardware and exploration benefits, the Higher Education Commission has founded an extraordinary award program. In this program, reserves are given to qualified public part colleges and degree granting foundations for fix and upkeep of logical gear.

\footnotetext{
${ }^{10}$ Aurangzeb, KA, and K Asif. "Good governance in universities, and prospects of employment for the students: evidence from Pakistan." Universal Journal of Management and Social Sciences 2 (11): 2012, 86103.
} 


\section{Institutional Strengthening Grant for Upgrading Laboratories and Libraries}

The Organizational Strengthening is intended to reinforce and upgrade the current Labs and Libraries of perceived public division Universities and perceived grounds. The goal of the program was to help advanced education organizations by giving awards of greatest 3 Million to overhaul their current labs and libraries so as to direct research study in various sectors. The award is to buy little to medium estimated logical hardware, library material based on solid legitimization and money saving advantage examination ${ }^{11}$.

\section{Library Support Grant}

The Library is one of the most significant part of a feasible advanced educational foundation. The Library Support Program of HEC is expected to reinforce and upgrade the current libraries of perceived public and qualified private division Universities in Pakistan. By this activity, Higher Education Commission plans to upgrade the information assets in libraries at Higher Education Institutions to give a potential scope of instructive and examination materials for understudies and staff and form them into information sharing focuses. The program broadens money related award for acquisition of library assets. The libraries may apply for financing from their scholarly establishment and the scholastic foundation will eventually look for subsidizing from HEC by applying for repayment. ${ }^{12}$

\section{Encouraging Education Programs for Underprivileged}

\section{Arrangement of Higher Education Opportunities for understudies of Baluchistan and FATA}

Applications are welcomed from the remarkable understudies of Baluchistan and recent FATA who mean to seek after Undergraduate concentrates in HEC-perceived public/private segment Universities/Degree Awarding Institutions of Pakistan. The Scholarships are being offered for the scholastic year 2020-21 in every aspect of study/disciplines under the undertaking named "Arrangement of Higher Education Opportunities for Students of Baluchistan and FATA.

\section{Ehsaas Undergraduate Scholarship Program}

Training past transitional is one of the approaches to beat destitution. Be that as it may, admittance to advanced education is itself conveyed unevenly. For instance, just $0.4 \%$ of the youngsters from the least salary quintile (from the pertinent age associate) are joined

\footnotetext{
${ }^{11}$ Bashir, Mohsin. Role of Organizational Power and Politics in the Success of Public Service Public Private Partnership. (Arizona: Arizona State University, 2012)

12 Amin, Muhammad, and Bilal Ahmad. "Dental education in Pakistan: current trends and practices." Journal of the College of Physicians and Surgeons Pakistan 8: 2010, 497-498.
} 
up with advanced education foundations, which is far beneath the public normal of $10 \%$. Ehsas grants plan to dispense with this wellspring of inconsistent access.

As per the National Human Development Report 2017, Pakistan is one of the most youthful nation on the planet. Understanding its segment reality which has a populace of around 220 million out of which the greater part are of college age companion, the need of Government of Pakistan is to take a shot at such projects which offer drive to give admittance to monetarily meriting and furthermore empowers sex value. The methodology is to make open doors for a sizeable section of youth to bring them under the net of advanced education and make equivalent instruction open doors for all.

\section{Improvement of faculty to meet the Emerging Education needs of the Country: Continuous Professional Development (CPD)}

Nonstop Professional Development (CPD) are run for proficient advancement of inadministration showing staff of public areas HEIs to carry them to global norms. The courses are supported by English Language Teaching Reforms Project and facilitated by educational institutions. They are from multi week to one month span and are offered by ELT workforce ${ }^{13}$.

The Continuing Professional Development courses were offered in accompanying territories:

- CALL (Computer Assisted Language Learning )

- T\&E ( Testing\& Evaluation )

- RMS ( Research Methodology and Skills )

- (Teaching Practicum, Communication Skills) Androgogical/Pedagogical Skills

- (EAP, ESP, ESL, ELT) Open and Customized Programs in ELT related territories

\section{National Academy of Higher Education (NAHE)}

HEC of Pakistan in June 2019, reported dispatch of the NAHE (National Academy of Higher Education)

NAHE is set up as an independent, self-sufficient organization working in sponsorship of Higher Education Commission to improve the nature of instructing, examination \& administration in HEIs across Pakistan. It is imagined as head foundation of quality examination \& instructing identified with all parts of higher education. It intends to:

- Giving a learning situation wherein personnel, staff and members can cooperatively grow, fundamentally inspect, save and offer information and qualities that establish the control of training in its widest sense.

- Attract and deliver people for differing social, monetary and traditional foundations, with specific receptivity to bunches that have been under delivered by advanced

\footnotetext{
13 Anwar, Lubna Shah. 2007. Higher Education Reform in Pakistan. https://wenr.wes.org/2007/12/wenrnovemberdecember-2007-feature.
} 
education.

- Make capable and caring instructors \& instructive heads to adjust content information and practice with a comprehension of understudies and networks they serve and grow expertly to be moral \& compelling chiefs \& pioneers.

- Prepare individuals from a worldwide network of instructors/researchers who direct exploration \& fill in as teachers, heads, strategy producers, and pioneers in advanced education.

\section{Civil Awards}

Grants are presented to the instructors and Universities in acknowledgment of their accomplishments \& administrations delivered for the improvement of foundation \& society.

The Government of Pakistan welcomes selections consistently for various classifications of (Civil) Awards to be declared by the President, Islamic Republic of Pakistan on $14^{\text {th }}$ August.

At HEC level, the accompanying Civil Awards are being managed:

- Hilal eImtiaz

- Sitara eImtiaz

- Pride of Performance

- Tamgha e Imtiaz

\section{Examination Travel Grant for University Faculty and Scholars}

Scholastic occasions are critical for proficient advancement of specialists and researchers. They fill in as a hotspot for direction, introduction, information sharing, creating linkages, also, critical thinking. Scholastic Meetings, Classes and Symposia give chances to academicians to help comprehend the most recent improvements in their sector and approve research discoveries and opening doors for future scholarly coordinated efforts.

Such occasions are foundations of scholarly condition. To develop such condition, the Advanced Education Commission (AEC) has set up an extraordinary Exploration Travel Award Reserve for College workforce, PhD researchers, and MS understudies at Colleges.

\section{Grant to Sort out Course, Meeting and Preparing Workshop}

Scholastic occasions are basic for sharing information and exploration between schools $\&$ researchers. The development of examination way of life in advanced schooling corporations via such occasions is of most noteworthy want to Advanced training Commission. To assist the advancement of exam tradition, HEC offers economic awards to Public Area Colleges and certified Private-Part Colleges in Pakistan to compose Public and Global Courses, Workshops, Meetings and Symposia. Through this hobby, HEC way 
to accumulate a culture of exploration and statistics sharing among Advanced education Organizations, just as foundation of linkages with relevant mechanical and company components. The candidate will observe for subsidizing from his/her scholarly business enterprise and the scholastic foundation will ultimately look for financing from HEC through making use of for reimbursement.

\section{Goals}

- Encourage Colleges and Degree Granting Organizations (DAIs) to compose scholastic occasions.

- Educate staff and understudies with the most recent advancements in their applicable regions of exploration

- Provide stage for communication and introduction to the scholars and scientists.

- create roads for sharing of information at public \& worldwide level occasions.

- Check scholastic \& exploration abilities and accomplishments at standard with the predominant public and worldwide practices.

- Share scholastic and exploration accomplishments with mechanical and business foundations.

- Explore open doors for homegrown and global scholarly joint efforts ${ }^{14}$.

\section{Improvement of Educational Plan in accordance with Global Guidelines}

\section{National Qualifications Framework of Pakistan}

The Pakistan Capability System is considered as instrument for grouping of the capabilities based on the learning results for example ability, capability, information. It is levels based and results centered. Pakistan Capability System (PQF) includes an extensive rundown of all quality guaranteed capabilities in Pakistan. The Pakistan Capability System gives all the data with respect to the authorized higher capabilities and organizations perceived by the Advanced education Commission of Pakistan.

\section{Destinations of the PQF}

- Assists to make accessible Quality Guaranteed and certify capabilities to all partners.

- Assists in setting up public principles of capabilities

- Deliver a foundation for examination of capabilities at public just as global standard.

\footnotetext{
${ }^{14}$ Bashir, Tariq, and Tariq Mahmood Ali. 2014. "Considering Local Dimensions in Building KnowledgeBased Economy in Pakistan." Building Knowledge-Based Economy in Pakistan: Learning from best Practices i 69 .
} 
- Helps in global acknowledgment of capabilities

- Assists the trans-public versatility of degree holders and students

- Helps to advance the linkages among industry and training framework

\section{Reading material and Monograph Composing Plan}

The Course reading and Monograph Composing Plan was made by the Advanced Education Commission for the particular motivation behind growing excellent writing and reading material to help scholarly equipment's in the advanced education area. In this plan, HEC encourages writers to compose on various branches of knowledge and orders applicable to graduate and postgraduate investigations.

\section{Targets}

- To advance scholarly composing aptitudes.

- To get scholarly contribution from essayists on public issues.

- To give a stage to authors to investigate and share their thoughts and data.

- To get ready and set up a strong group of writers at tertiary level.

- To make a journalist gathering and organize its yearly gathering.

- To make accessible ease course books for understudies and instructors.

- To create monographs that will give sharp information in center territories alongside uncommon themes.

\section{Improvement of Exploration and Advancement arrangement of Nation Observing and Assessment Division}

The M\&E Division was first settled in Higher Education Commission as Arranging and Observing Cell in 2003 through an improvement venture. During a gathering of ECNEC hung on February 18, 2004, it was concluded that every Service/Division will set up Arranging and Checking Cells from non-improvement spending plan to design, assess, screen and assess the advancement ventures. It was later changed from venture subsidized arrangement to an undeniable Checking and Assessment Division of HEC.

The focal point of division's obligation sanction centers around checking, encouraging, and helping fruitful endeavor of the tasks just as to guarantee execution of ventures according to scope inside affirmed budgetary arrangements and timetables ${ }^{15}$.

\footnotetext{
15 Mahmood, Khalid. 2016. Overall Assessment of the Higher Education Sector, (Islamabad: Higher Education Commission, 2016) https://hec.gov.pk/english/universities/projects/TESP/Documents/FRAssessment $\% 20 \mathrm{HE} \% 20$ Sector.pdf.
} 


\section{Ph.D. Survey Boards}

Advanced education assumes an indispensable function in the financial improvement of nation and Higher Education Commission considers limit working of the Degree Granting Establishments as significant for reason. Thus, nature of $\mathrm{PhD}$ scientists/teachers delivered is the spine for the improvement of Value Instruction in organizations of Advanced Learning. To guarantee the nature of doctorate level training, HEC stepped up of beginning PhD Progress Survey Cycle. Considering the significance of outer quality affirmation instrument for Ph.D. Projects, the Quality Confirmation Office, HEC in conference with existing Ph.D. Survey Advisory group individuals changed the whole audit measure.

The Equipped Authority establishes a PhD Survey Council involving prominent scholars to decide the execution status of set down measures. It was concluded that appraisal of MPhil/PhD programs consistently be proceeded so as to guarantee the nature of projects. For this reason, standard information assortment and survey visits of colleges are embraced. So as to quicken the audit cycle, four survey advisory groups are working.

\section{MS M.Phil. Survey Panel}

The QAA, HEC got the command to guarantee and upgrade the nature of advanced learning by concocting feasible procedures. Thinking about the significance of executing of Outside Quality Confirmation Component; the Quality Affirmation Association, Higher Education Commission has set up Attestation Boards for quality affirmation of undergrad capabilities in various trains and started Ph.D. Program Survey Cycle for quality affirmation of Doctoral capabilities.

Because of mushroom development of Degree Granting Establishments (DAIs) and expanding request of higher capabilities, practically all the Degree Awarding Institutions and their Board and Partnered Foundations have begun MS/M. Phil. what's more, identical projects. Sadly, there is no quality affirmation instrument produced for these projects, thus these capabilities are being offered and granted without going through any Outside Quality Confirmation Component. Advanced education Commission stepped up to the plate of beginning MS/MPhil and Identical Degree Program Audit Cycle to guarantee the nature of MS/MPhil and Proportional level training.

\section{National Exploration Program for Universities}

Public Exploration Program for Colleges (NRPU) is a lead Exploration Program of HEC for subsidizing research awards on serious legitimacy for elevated level and promising logical examination extends that exhibit vital importance and effect on nearby industry and society. So as to offer monetary help for fundamental and applied examination for specialists across Pakistan, NRPU has been serving the country for over 10 years to give a stage to academicians to win awards for essential and applied exploration. The principle focal point of this program is to seriously choose research extends that will address public needs through supporting essential and applied examination just as translational 
exploration/trial and extraordinary exploration so as to push examination to do nation explicit, issue put together having sway with respect to society. HEC means to animate associations between scholastic specialists and end-clients.

\section{Offices of Research, Innovation and Commercialization (ORICs)}

HEC targets persuading and encouraging the Higher Education Institutions (HEIs) to focus on research for a supportable financial development and future information economy. For this reason, a middle is being set up in colleges to fill in as a vital point, including all the examination exercises - from advancement of exploration proposition to the commercialization of examination items - under a solitary umbrella. These focuses will be designated "Workplaces of Research, Innovation and Commercialization (ORICs)".

HEC has begun attempting to arrange the exploration exercises of colleges/HEIs guaranteeing accessibility of settled and completely practical ORICs. These ORICs will offer vital and operational help to the exploration exercises/projects of a college and it will have a focal function in encouraging the result of the colleges investigates. These explores will zero in essentially on turning creation (unadulterated information) into development (items and creation measures) that can at last effect the government assistance of network government assistance.

\section{Topical Research Grants Program}

Advanced education segment of Pakistan has been assuming a significant part in enhancing nature of instructing and creating research practice through imaginative ways. Understanding the need of guaranteeing the idea of information economy in evident sense it started diverse boosted programs in colleges/foundations to persuade and energize the possible analysts in practically all orders. Nonetheless, other than its emphasis on advancing examination culture in sciences it likewise focused on advancing exploration culture in sociologies. It, subsequently, expects to empower the inventive and skilled employees to test into those territories (see the diverse topical regions in connection) that review the development and improvement of Pakistan. Such consolation not just aides in tending to the main points of interest incapacitating the status of Pakistan yet in addition uncovering those conceivable contextual investigations and subtleties which can be converted into public strategies and objectives accomplishments ${ }^{16}$. Moreover, topical exploration program in sociologies plans to demoralize the on-going cerebrum channel and using the imaginative considering analysts.

\section{Innovative \& Collaborative Research Grant (ICRG)}

Innovative and Collaborative Research Grant (ICRG) underpins research associations among Pak and Britain colleges, research organizations and present focuses of greatness

\footnotetext{
${ }^{16}$ Kumari, Roshni. 2015. "Review of Research Performance in Higher Education Sector in the Last." (Islamabad, 2015), https://www.hec.gov.pk/english/universities/projects/TESP/Documents/TESA\%20Report\%20$\% 20$ Research\%20Performance.pdf.
} 
that emphasis on any of rising controls/need regions. The target of the award is to help shared examination among Pakistan and UK for front line exploration and advancement in rising controls of information

\section{Start-Up Research Grant for new PhD holders}

SRGP is intended to help the new PhD holders set under HEC program, IPFP to set up research offices after joining advanced education establishments as IPFP Fellow. The program empowers the recently delegated $\mathrm{PhD}$ staff to arrangement essential exploration framework to begin research exercises immediately. The program assists with drawing in both the workforce and understudies in research through arrangement of monetary help and essential lab/test offices.

\section{Problem Based Applied Interdisciplinary Research Programme (PBAIRP)}

The Higher Education Commission points "to encourage organizations of higher figuring out how to fill in as motors for financial improvement of Pakistan" as expressed. In accordance with announcement, HEC of Pakistan showed a drive to fund proposition of integrative exercised exploration ventures on a particular subject tending to nearby issue/issue. Along these lines, HEC imagines to help the profitable personalities to affect economy by new and developing innovations.

Interdisciplinary is a way to address complex issues that can't be managed from a solitary disciplinary viewpoint alone. These issues need individuals from various viewpoints to cooperate, sharing thoughts, speculations and practice to arrive at suitable arrangements. Interdisciplinary examination and powerful joint effort between individuals from various orders give significant advantages to researchers, strategy creators and different partners to augment the expected advantages of interdisciplinary for future exploration movement.

To encourage interdisciplinary and create space to grow more inventive \& high sway research that conveys answers for the difficulties confronting Pakistan, HEC started an Interdisciplinary examination award program-Problem Based Applied Interdisciplinary Research Program (PBAIRP) that is particularly intended to deal the present issue of the nation and to think of improved and applicable responses to confront the contemporary issues of the nation through integrative methodology.

\section{Local Challenge Fund (LCF)}

The LCF is a basic component of the Advanced Education Progress in Pakistan Project backed by the World Bank and actualized by the HEC. The LCF is foreseen to help research extends important financial issues and will give assets to choose establishments dependent on a serious, peer-audited assessment of proposition.

\section{Key Objectives}

- To uphold cross-disciplinary examination extends any of the 17 SDG (Sustainable Development Goals) at the area level. 
- To fortify the neighborhood college research limit and to add to the exploration mission of the host organization in unraveling nearby issues.

\section{Improvement of Inter-Relationship between Industry and HEIs of the Country}

\section{Social Integration Outreach Program}

As the worldwide patterns in training change to oblige the new difficulties, the objectives of Higher Education Institutions continue switching to stay aware of global patterns. Advanced education Commission gives direction and backing to the Higher Education Institutions (HEIs) to stay up with these global patterns. This particular plan is intended to push colleges to incorporate their exploration and instructing exercises to deal neighborhood issues, by network contribution, to give on ground arrangements. Through this program HEIs will give a stage to the neighborhood network, in span of every grounds, where issue recognizable proof, advancement and execution of arrangements will be done.

\section{Business Incubation Centers in Public Sector Universities}

The HEC upholds the foundation of Business Incubation Center's (BIC) in open area colleges to give essential framework and partnered offices for specialists and youthful business people who are keen on growing beginning phase undertakings. A business hatchery's primary objective is to deliver effective firms that will leave the program monetarily feasible and detached.

Business Incubators organizations are, which uphold new businesses in their underlying improvement stage by giving a variety of focused assets and administrations. These administrations are created or orchestrated by the business hatchery and offered by it legitimately. Alumni of new business hatchery program make occupations, renew neighborhoods, popularize new advancements, and fortify nearby and public economies. Rather than making position searchers we are transforming new alumni into work suppliers ${ }^{17,18}$.

\section{The University Industry Technology Support Program for Researchers}

The UITSP of the HEC is a significant advance to encourage an elevated level of substantial collaboration among the scholarly community and industry. This participation is to benefit from developing global requests for items and cycles in discrete and persistent assembling that will add to the public economy.

This program is centered around the modern segments where the nation is as of now a significant supporter of world exchange. It centers around outfitting the capability of exceptionally serious parts for global exchange which needs advancement both for nearby

\footnotetext{
${ }^{17}$ Abdullah, Tariq. "Making Pakistan Universities Centres for Research: A Case Study of the Centre for Solid State Physics." Lahore Journal of Policy Studies (Lahore School of Economics, 2008) 111-123.

${ }^{18}$ Bano, Shah. Southampton. The Role of Universities in Transforming A Developing Economy into A Knowledge-Based Economy: The Case of Pakistan, (University of Southampton, 2012).
} 
and worldwide utilization. The engaged part insightful recognizable proof of items and cycles in discrete and consistent, just as import and fare, patterns is accessible from the public area nearby and global measurable information.

The UITSP suggests that scientists, ideally with $\mathrm{PhD}$ degrees and association with global expert bodies, work together with the nearby business engaged with discrete and nonstop assembling for unmistakable outcomes regarding improvement of item and cycles prompting diminished import of crude material and expanded fare of the completed item and cycles. The items and cycles requiring improvement ought to preferably be in need regions applicable to public requirements for financial advancement of the nation.

The UITSP is granted on serious legitimacy by HEC for significant level and bright modern examination tasks of research \& modernization. In addition, it allows HEC to tie college investment to accomplishments within the sector of network, community and enterprise synergy.

\section{Pakistan - United States Science and Technology Cooperation Program}

In 2003, the Governments of Pakistan and USA marked a total Science and Innovation Participation Understanding that set up a system to development participation in innovation, period, designing and preparing for common advantage and non-savage purposes among the mechanical know-how and preparing communities in each country. In 2005, USA Office for Universal Advancement (USAID) joined with the Service of Science and Innovation (MOST) and the Higher Instruction Commission (HEC) of Pakistan to help the joint Pakistan-United States Science and Innovation Participation Program. Starting in 2008, USA Division of State (DoS) joined USAID as a U.S. Cosponsor of this framework. This application is carried out with the help of the National Institute of Sciences (NAS) inside the U.S. and by the Higher Instruction Commission (HEC) in Pakistan. It is gathered to boom the power and breadth of participation and linkages between Pakistani researchers and foundations with inverse numbers inside. This software is carried out with the resource of the National Academy of Sciences (NAS) within the U.S. and by the Higher Education Commission (HEC) in Pakistan. It is supposed to increase the electricity and breadth of cooperation and linkages between Pakistani scientists and enterprises with opposite numbers inside the United States. Within NAS, the Pakistan - U.S. Science and Technology Cooperation Program is administered by using the use of the Development, Security, and Cooperation unit inner the Policy and Global Affairs Division.

\section{Program Objectives}

Projects funded underneath this solicitation have to make contributions to setting up research capability in Pakistan while strengthening U.S. - Pakistan cooperative relationships in one or greater of the following methods:

- Enhancing the capacity of the science and era community to spur human and monetary development in Pakistan.

- Developing the quality and capacity of education and research at HEIs of better 
training in technological know-how and technical sector.

- Developing the capability of Pak studies establishments to aid competitiveness.

\section{Pakistan Program for Collaborative Research (PPCR)}

Pakistan Program for Collaborative Research lets in for scholars/faculty/researchers in Pakistan to travel abroad. Priority is given to participants travelling overseas establishments which have diagnosed excellence within the related research. The tours are restrained to 1 person (the visiting person) getting to a minimum of one institute within the host group. The touring fellow and the host are co-candidates of the concept. The foremost purpose of this grant, that's hospitable all fields of research, is to build up global partnerships.

\section{PERIDOT Research Program}

PERIDOT is a Franco-Pakistani Hubert Curien Partnership (PHC) Program supplying possibilities to researchers to interact for combined studies sports. This software is implemented in Pakistan by HEC and in France, at an equivalent time by MAEDI and MESRI. The purpose of this venture is to expand new clinical and technological cooperation between Pak-French institutions/research labs by assisting researchers from each aspect.

The preference areas in 2020 have been:

(a) Environmental Sciences (which includes Pollution, Global climate and Water)

(b) Energy

(c) Health

(d) Human and Social Sciences

\section{Pak-Turk Researchers' Mobility Grant Program}

Pak-Turk Researchers' Mobility Grant Program 2017 is one of the upshots of Pak-Turk collaboration in scope of international efforts of higher education structures. It is implemented in Turkey through the CoHE and in Pakistan by the HEC.

The purpose of this program is to broaden new clinical and technological collaboration between both country's advanced training establishments by assisting the graduate students and educational team of workers.

HEC and the Turk counterpart will offer travel funds and residing cost to the researchers for their authorized tasks.

The preference areas in 2019-20 were;

- $\quad$ Energy

- Food Technology

- Sustainable Environment Technology 
- Material Sciences

- Smart Transport Systems

- $\quad$ Robots \& Smart Systems

\section{Technology Transfer Support Fund (TTSF)}

The TTSF is a basic element of Advanced Learning Development in Pakistan Project backed by the World Bank and applied through the HEC. The TTSF is anxious to aid bright partnerships among academia and enterprise to entertain the switch of university evolved technological studies to enterprise and the industrial area.

The TTSF seeks to help college generation research that has previously advanced a current prototype or a sophisticated version (or equal). The predicted portfolio of TTSF initiatives will guide higher training establishments throughout Pakistan to adopt research and improvement activities targeted on technology switch. TTSF initiatives are predicted to expand services or products which can be marketable and can generate fine coins glide.

\section{Methodology}

This study is an exploratory study to find out the role of HEC in higher education institutes on the basis of projects of HEC regarding learning environment in country. In order to collect data primary data, conduct a survey of higher education institutes to examine the formal learning programs and secondary data collected from journals, newspaper magazines annual reports of HEC.

A simple convenience sampling method has been used to carry out the study. A total of 500 respondents were contacted from the population. Descriptive research has been conducted to gain insight the various programs projects of HEC to enhance the learning environment in Pakistan. Close ended questionnaire has been used as a research tool with five-point Likert's Scale (5=Strongly Agree, 4=Agree, 3=Neutral, 2=disagree, 1=strongly disagree)

\section{Findings and Discussion}

This section represents the findings about formal learning and development in comparison with public and private higher education institutes. When we conduct research about the presence of PhD faculty members it shows that Majority $74.8 \%$ of $\mathrm{Ph}$. D faculty members are actively involved in research at the department in public institutions while $58 \%$ faculty members are engaged in research activities in private institutes.

Majority $60.7 \%$ of faculty members in the private institutes (figure2) shows that the department has not the adequate physical facilities for conducting the research with the comparison of public sector faculty members' i.e., $49 \%$.

From the Figure 3 it has shown that $63 \%$ faculty members of private sector feels that they have skilled workforce in comparison with the public institutions that constitutes $50 \%$. 
Majority $(61.5 \%)$ of the public sector faculty members feels that collaborative research has contributed to the institutional research capacity in comparison with the $40 \%$ faculty member of the private institutes agree with this fact. Figure 4

It has shown in Figure 5 that $66 \%$ faculty members of private institutes has feel that ORIC has not much support in collaborative research in comparison with the $61 \%$ faculty members of public institutes agree with this fact. It shows the lacking of interdepartmental collaboration.

Figure 6 shows that $75 \%$ faculty member of private institutes agree with this fact that the research funding opportunities are not sufficient while $46 \%$ faculty members of public institutes agree with this fact.

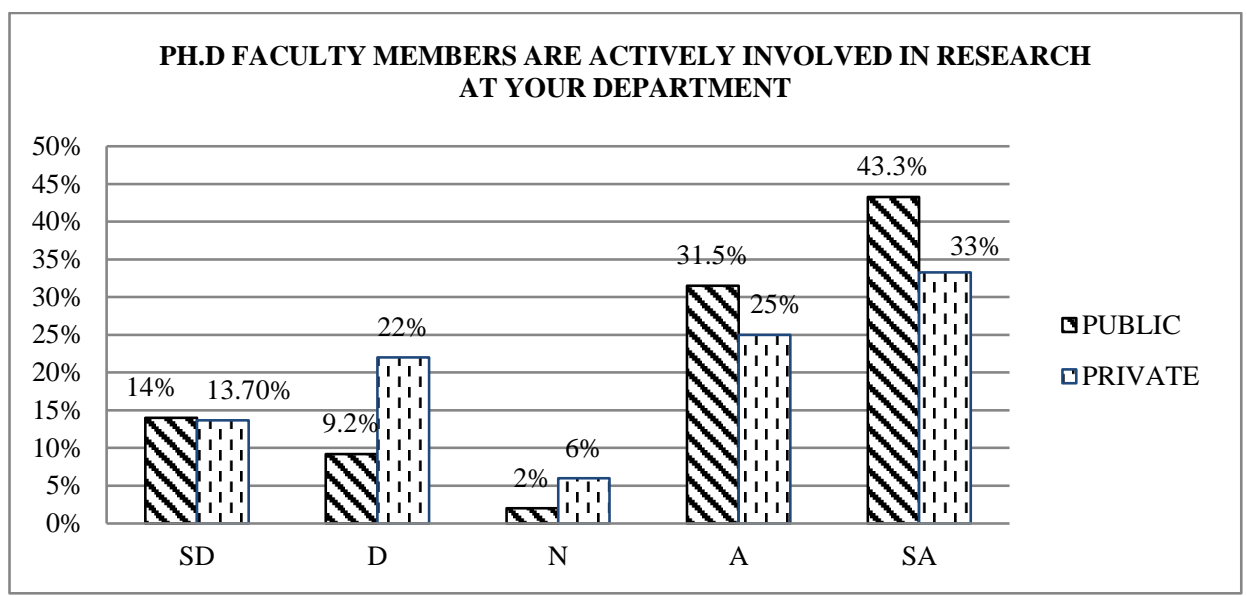

Figure 1

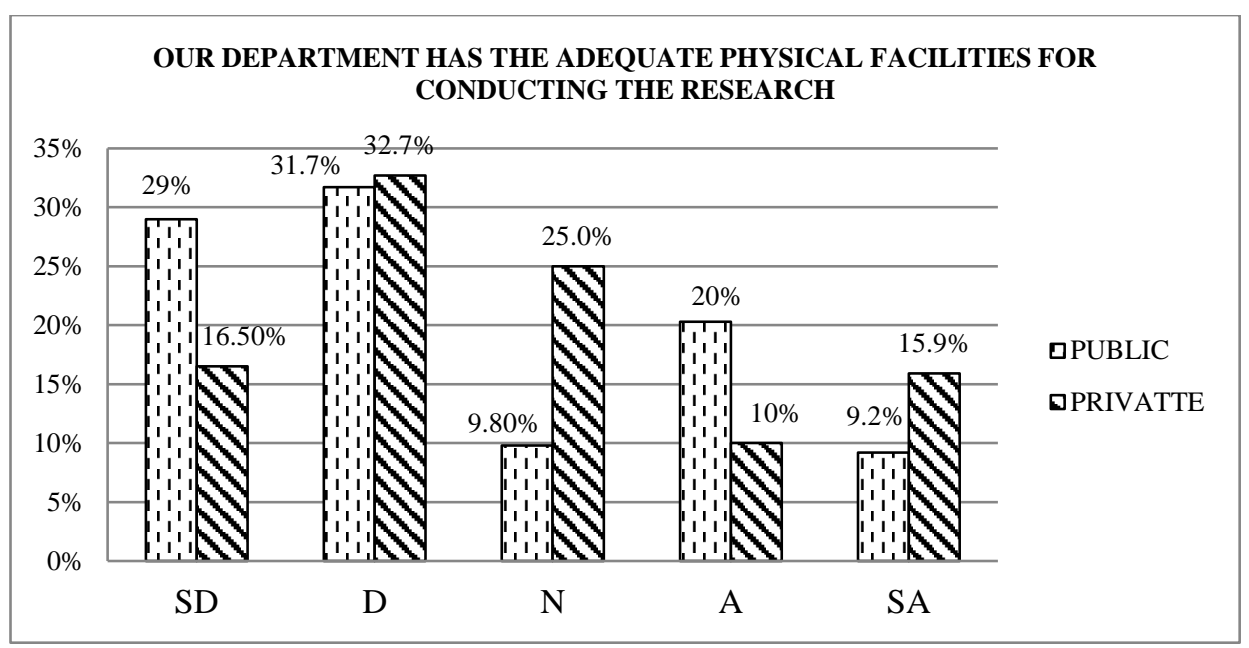

Figure 2 


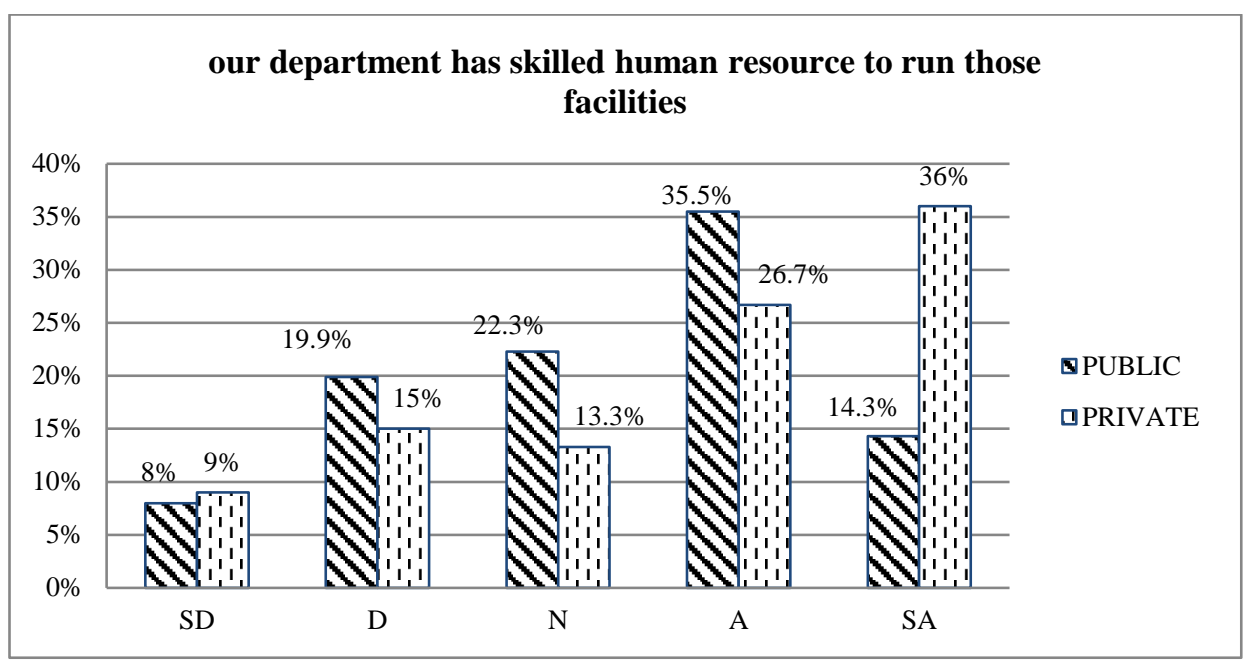

Figure 3

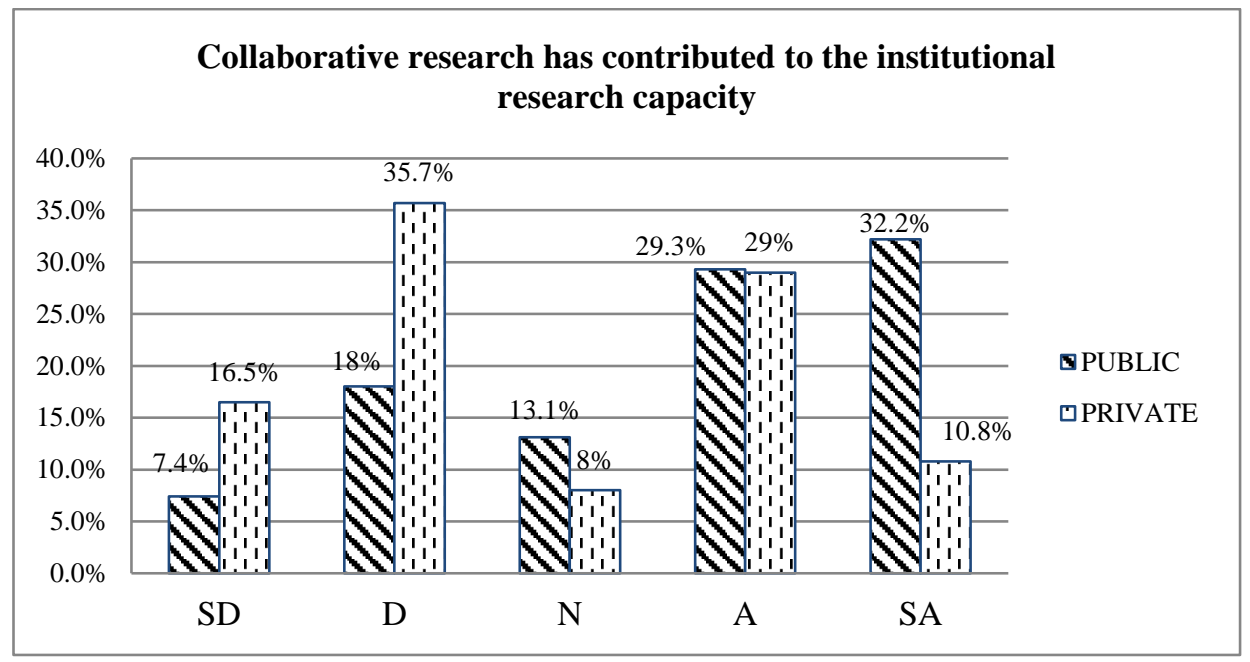

Figure 4 


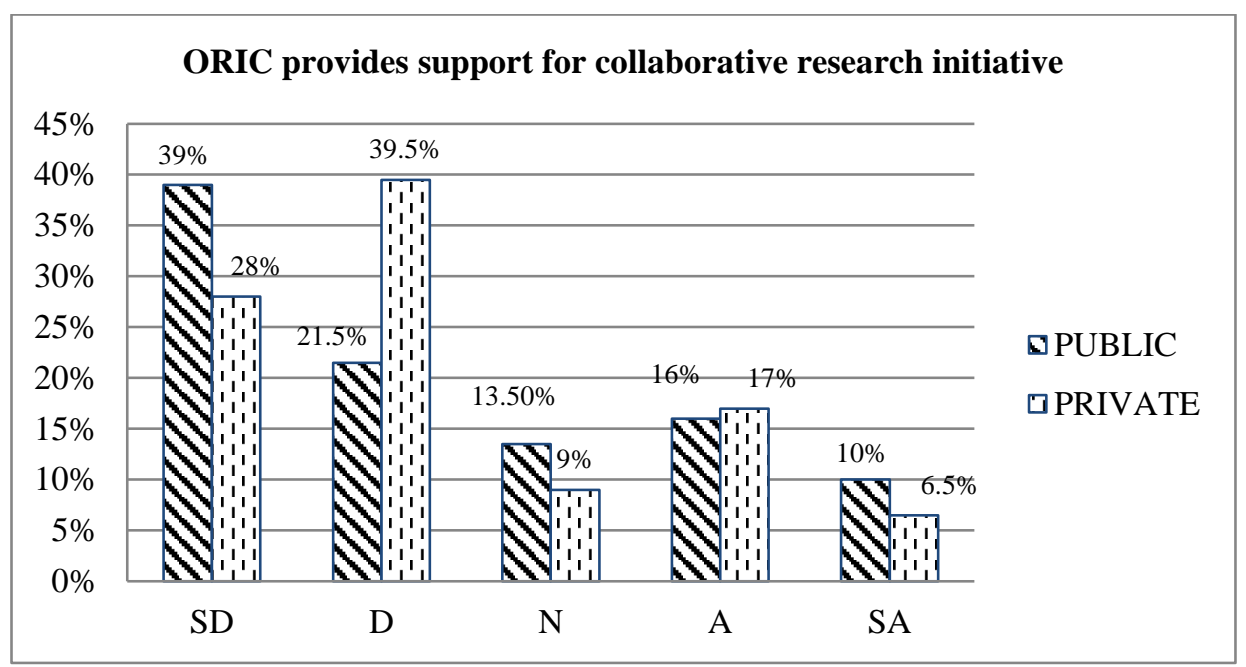

Figure 5

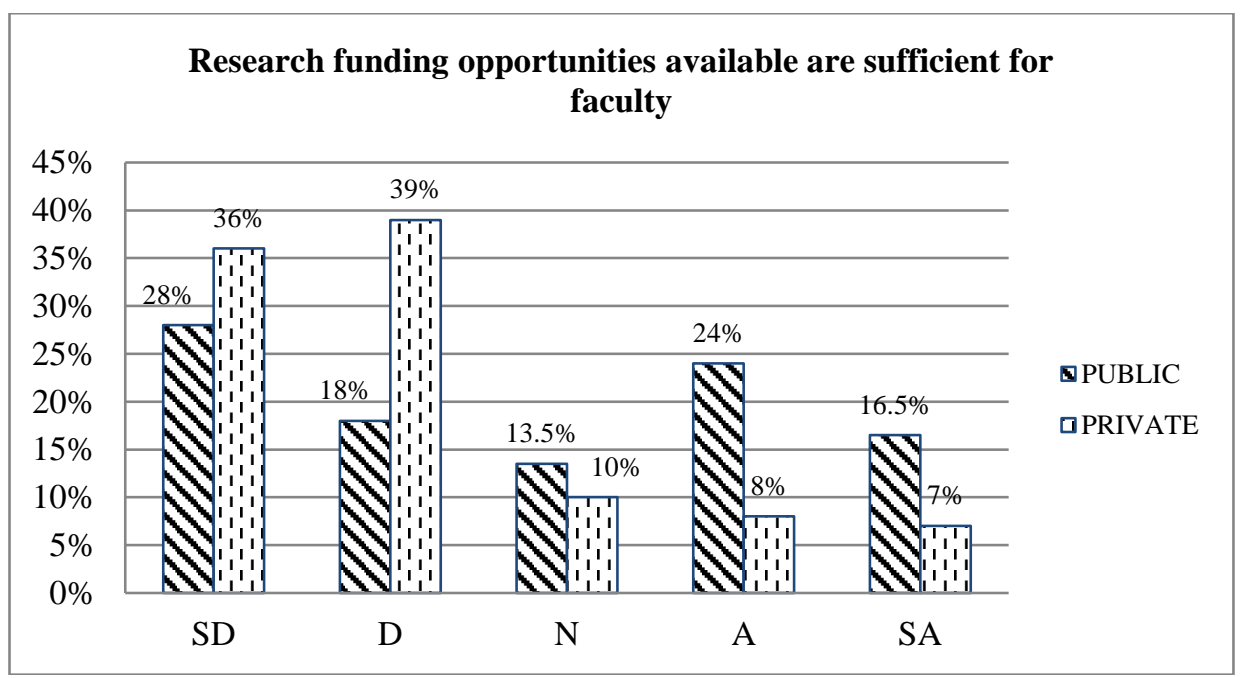

Figure 6

\section{Conclusion}

HEC considering that its inception has executed a wonderful provider to the getting to know environment of Pakistan and continues to impact the education surroundings undoubtedly. If the reforms and the programs inaugurated with the aid of HEC continue to transport inside the current course, we can have a new technology of development. The 
efforts of HEC have not handiest been observed internationally, however it's far taken into consideration one of the pleasant efforts in training reforms in contemporary history.

German educational, Dr. Wolfgang Voelter of Tubingen University from Germany complimented and described the reforms as "A miracle took place" under the management of Prof. Atta ur Rahman. After educating and visiting in 15 universities in Pak, Voelter wrote that "the situation of education and technological knowledge in Pakistan has changed dramatically, as by no means before in the history of the Pakistan. Thomson Reuters in an independent evaluation of Pakistan's progress in international publications has recounted that in the last decade there was a fourfold increase in global publications and a tenfold boom in pretty mentioned papers, records that had been better than the BRIC international locations ${ }^{19}$.

\section{Accomplishments of HEC}

The introduction of fee had a marvelous impact on better education and studies lifestyle.

Built the finest Digital Library. Every scholar/educationist in each university has got entry to 45,000 textbooks, research monographs from 220 international publishers as well as to 25,000 international research journals.

Tripled University enrollments from $135 \mathrm{~K}$ in the 12 months of 2003 to $400 \mathrm{~K}$ in 2008

Boosted research, ensuing in et extra ordinary enlargement of international study guides from handiest 600 research papers in 2003 to 4300 study papers in 2008

During the 55years (1947-2002) of independence and 28 years (1974-2002) of University Grants Commission, not a single Pakistani college was ranked among the 600 universities in the world. In 2002, seven Pak universities became ranked for the first time in top 250 universities of Asia according to QS World University Rankings 2013.

Four-12 months undergraduate application delivered in order that tiers are across the world recognized together with a 3-credit score hour research based totally interest and implementing a minimum attendance.

About 5000 scholarships awarded for Ph.D. Degrees for observe in technologically superior international locations (biggest software in growing world) and 3,000 indigenous Ph.D. Scholarships had been presented. The international's largest Fulbright Scholarship program (US \$one hundred fifty million) launched with mutual investment (HEC/USAID)

51 new universities and DAIs and 18 campuses of current universities hooked up all through

Sending one thousand Pak students to study remedy in Cuba.

\footnotetext{
${ }^{19}$ Amjad, Rashid. "Why Pakistan must break-into the knowledge economy." Lahore Journal of Economics, 2006, 75-89.
} 
Research output of Pakistan increased by over $50 \%$ within 5 years which became the $2^{\text {nd }}$ highest boom global. In 2017, a Chinese examine published in Scientometrics revealed that Pakistan's research boom fee and time required to double the wide variety of publications is superior to that of USA, China and India.

\section{Bibliography}

Abdullah, Tariq. 2008. "Making Pakistan Universities Centres for Reseach: A case study of the Centre for Solid State Physics." Lahore Journal of Policy Studies (Lahore School of Economics) 111-123.

Amin, Muhammad, and Bilal Ahmad. 2010. "Dental education in Pakistan: current trends and practices." Journal of the College off Physicians and Surgeons Pakistan 8: 497-498.

Amjad, Rashid. 2006. "Why Pakistan must break-into the knowledge economy." Lahore Journal of Economics 75-89.

Ansari, Seema, Javier Poncela, Pablo Otero, Adeel Ansari, and Osama Mahfooz. 2016. "Research in Pakistan: structure, funding and results." Pakistan Journal of Engineering, Technology \& Science 5 (1).

Anwar, Lubna Shah. 2007. Higher Education Reform in Pakistan. https://wenr.wes.org/2007/12/wenr-novemberdecember-2007-feature.

Aurangzeb, KA, and K Asif. 2012. "Good governance in universities, and prospects of employment for the students: evidence from Pakistan." Universal Journal of Management and Social Sciences 2 (11): 86-103.

Bano, Shah. Southampton. The role of universities in transforming a developing economy into a knowledge-based economy: the case of Pakistan. 2012: University of Southampton.

Bashir, Mohsin. 2012. Role of organizational power and politics in the success of public service public private partnership. Arizona: Arizona State University.

Bashir, Muhammad. 2013. "Knowledge economy index (KEI) 2012 rankings for Islamic countries and assessment of KEI indicators for Pakistan." International Journal of Academic Research in Economics and Management Sciences (Citeseer) 2 (6): 28.

Bashir, Tariq, and Tariq Mahmood Ali. 2014. "Considering Local Dimensions in Building Knowledge-Based Economy in Pakistan.” Building Knowledge-Based Economy in Pakistan: Learning from best Practices $i 69$.

Bhutani, S. 2013. "Re-Searching Agriculture in South Asia: The law and policy context for agricultural research and development and its impact on smallholder farmers." International Institute for Environment and Development (IIED), London. 
Bukhari, S. M. H., and M Asim. 2013. "Policy Making and Is Impacts on Higher Education: A Comparative Study of Iran and Pakistan in 21 st Century." Policy 5 (1).

HEC. 2021. Qualit Assurance Agency.

https://www.hec.gov.pk/english/services/universities/QAA/Pages/default.aspx.

-. 2021. The Modern University Program.

https://www.hec.gov.pk/english/services/faculty/MUGUA/Pages/Introduction.aspx.

Higher Education Commission. 2017. HEC Vision 2025.

https://www.hec.gov.pk/english/HECAnnouncements/Documents/Announcement/HECVision-2025.pdf.

Higher Education Commission. 2016. Higher Education Medium Term Development Framework 2011-15. Islamabad: Higher Education Commission, 8.

Javed, Saad Ahmed, and Sifeng Liu. 2018. "Predicting the research output/growth of selected countries: application of Even GM $(1,1)$ and NDGM models." Scientometrics (Springer) 115 (1): 395-413.

Kumari, Roshni. 2015. "Review of Research Performance in Higher Education Sector in the Last." Islamabad.

https://www.hec.gov.pk/english/universities/projects/TESP/Documents/TESA\%20Repo rt\%20-\%20Research\%20Performance.pdf.

Mahmood, Khalid. 2016. Overall assessment of the higher education sector. Islamabad: Higher Education Commission. https://hec.gov.pk/english/universities/projects/TESP/Documents/FRAssessment $\% 20 \mathrm{HE} \% 20$ Sector.pdf.

Thomson Reuters. 2016. "Pakistan: Another BRC in the Wall." http://images.info.science.thomsonreuters.biz/Web/ThomsonReutersScience/\%7Bdab71 dc1-d7d8-48af-88a6-fa7efa61ae22\%7D_Pakistan_Citation_Report_FINAL.pdf.

Voelter, Wolfgang. 2008. The golden period. Dawn area studie. 